\title{
INFLUENCE OF SOIL COVER ON PORE DISTRIBUTION AND CONNECTIVITY DENSITY IN A FERRALSSOL EVALUATED BY 3D COMPUTERIZED MICROTOMOGRAPHY
}

\author{
https://doi.org/10.4215/rm2019.e18029
}

Marcelo Wermelinger Aguiar Lemes a* - Alessandra Silveira Machado b - Gustavo de Mattos Vasques c Hugo Machado Rodrigues ${ }^{d}$ - Ricardo Tadeu Lopes e - Reiner Olíbano Rosas ${ }^{f}$

(a) Dr. in Geography. Professor Estácio de Sá, Rio de Janeiro (RJ), Brazil.

ORCID: https://orcid.org/0000-0002-2438-7882. LATTES: http://lattes.cnpq.br/1575146503306464.

(b) Dr. in Nuclear Engineering. Federal University of Rio de Janeiro, Rio de Janeiro (RJ), Brazil.

ORCID: https://orcid.org/0000-0002-7973-9611. LATTES: http://lattes.cnpq.br/8739325293069871.

(c) Dr. em Soil and Water Science. Researcher at Brazilian Agricultural Research Corporation, Rio de Janeiro (RJ), Brazil.

ORCID: https://orcid.org/0000-0001-9463-1898. LATTES: http://lattes.cnpq.br/1838153897546051.

(d) Msc. Student in Agronomy . Federal University of Rio de Janeiro, Rio de Janeiro (RJ), Brazil.

ORCID: https://orcid.org/0000-0002-8070-8126. LATTES: http://lattes.cnpq.br/1594791643571293.

(e) Dr. in Nuclear Engineering. Professor Federal University of Rio de Janeiro, Rio de Janeiro (RJ), Brazil.

ORCID: https://orcid.org/0000-0001-7250-824X. LATTES: http://lattes.cnpq.br/8246131317396176.

(f) Dr. in Geography. Federal University Fluminense, Rio de Janeiro (RJ), Brazil.

ORCID: https://orcid.org/0000-0002-9671-2410. LATTES: http://lattes.cnpq.br/4484335621458630.

\section{Article history:}

Received 1 October, 2019

Accepted 30 October, 2019

Publisher 15 December, 2019
(*) CORRESPONDING AUTHOR

Address: UNESA, Av. Marechal Fontenelle, 3555, Jardim Sulacap - CEP: 21740-001

Rio de Janeiro (RJ), Brasil. Tel: (+55 21) 984159440

E-mail: E-mail: marcelowlemes@hotmail.com

\begin{abstract}
In the search for new techniques aimed at complementing and adding new data on Ferralsols, high resolution computer microtomography (microCT) appears as a non-destructive and fast analytical technique. MicroCT has been outstanding in the international scenarios and it is more and more present in soil analyses. Analyzing a soil sample by microCT allows obtaining knowledge, in microscale, on shape, size, distribution, volume, area and pore connectivity and having a 3D visualization of the soil sample and its structure. The objective of this work is to use microCT to compare the porosity distribution and pore connectivity density between a soil without vegetation cover and a soil with grass cover, both Ferralsols. Four undisturbed samples of each soil were collected. The results show that the MicroCT technique is an efficient and non-destructive tool for the analysis and characterization of the pore structure of soils protected from and degraded by erosion, underlining clear differences between them, as expected.
\end{abstract}

Keywords: Porosity Soil, Microtomography Technique, Structure of Soil.

\section{Resumo / Resumen}

INFLUÊNCIA DA COBERTURA DO SOLO NA DISTRIBUIÇÃO DE POROS E DENSIDADE DE CONECTIVIDADE EM UM LATOSSOLO AVALIADO ATRAVÉS DA MICROTOMOGRAFIA COMPUTADORIZADA 3D

Na busca por novas técnicas que visem complementar e agregar novos dados sobre Latossolos, a microtomografia computadorizada de alta resolução (microCT) aparece como uma técnica analítica não destrutiva e rápida. A MicroCT tem se destacado nos cenários internacionais e está cada vez mais presente nas análises de solo. A análise de uma amostra de solo por microCT permite obter conhecimento, em microescala, da forma, tamanho, distribuição, volume, área e conectividade dos poros e ter uma visualização 3D da amostra de solo e sua estrutura. O objetivo deste trabalho é utilizar microCT para comparar a distribuição da porosidade e a densidade de conectividade do poro entre um solo sem cobertura vegetal e um solo com cobertura de grama, ambos Latossolos. Quatro amostras não perturbadas de cada área foram coletadas. Os resultados mostram que a técnica MicroCT é uma ferramenta eficiente e não destrutiva para a análise e caracterização da estrutura porosa dos solos protegidos e degradados pela erosão, evidenciando claras diferenças entre eles, conforme esperado.

Palavras-chave: Porosidade do Solo, Técnica de Microtomografia, Estrutura do Solo.

INFLUENCIA DE LA COBERTURA DEL SUELO EN LA DISTRIBUCIÓN DE POROS Y DENSIDAD DE CONECTIVIDAD EN UN LATOSOL EVALUADO A TRAVÉS DE LA MICROTOMOGRAFÍA COMPUTARIZADA 3D

En la búsqueda de nuevas técnicas destinadas a complementar y agregar nuevos datos sobre Ferralsoles, la microtomografía computarizada de alta resolución (microCT) aparece como una técnica analítica no destructiva y rápida. MicroCT ha sido sobresaliente en los escenarios internacionales y está cada vez más presente en los análisis de suelos. El análisis de una muestra de suelo mediante microCT permite obtener conocimiento, a microescala, de la forma, el tamaño, la distribución, el volumen, el área y la conectividad de poros y tener una visualización 3D de la muestra de suelo y su estructura. El objetivo de este trabajo es utilizar microCT para comparar la distribución de porosidad y la densidad de conectividad de poros entre un suelo sin cubierta vegetal y un suelo con cubierta de pasto, ambos Ferralsoles. Se recogieron cuatro muestras inalteradas de cada suelo. Los resultados muestran que la técnica MicroCT es una herramienta eficiente y no destructiva para el análisis y la caracterización de la estructura de poro de los suelos protegidos y degradados por la erosión, subrayando diferencias claras entre ellos, como se esperaba..

Palabras-clave: Suelo de Porosidad, Técnica de Microtomografía, Estructura del Suelo. 


\section{INTRODUCTION}

The pores of the soil are represented by cavities with different sizes and shapes, determined by the arrangement of solid particles which constitute a volumetric fraction of the soil filled with air, water and nutrients solution (Hillel, 1972). The soil porosity influences in aeration, water conduction and retention, resistance to penetration and branching of the roots in the soil and, consequently use of available water and nutrients (Tavares Filho, J. \& Tessie, Stubff et al, 2014). Several techniques can be used to obtain soil porosity index. In the search for new techniques aimed at complementing and adding new data on Ferralsols, high resolution computer microtomography (microCT) appears as a non-destructive and fast analytical technique. MicroCT has been outstanding in the international scenarios and it is more and more present in soil analyses. Analyzing a soil sample by microCT allows obtaining knowledge, in microscale, on shape, size, distribution, volume, area and pore connectivity and having a 3D visualization of the soil sample and its structure.

The microCT provides high resolution images with a set of volume data of an inspected sample that does not need to be modified and no preparation method has been submitted. Its physical principle is based on the attenuation of the X-rays when they interact with the object and are modulated according to the physical characteristics. To obtain microCT images, it is necessary to acquire many projections at constant angular steps and the reconstruction is performed with an appropriate algorithm based on the filtered overhead, (Machado et al., 2015)

Soil attributes can be visualized, quantified and simulated using three-dimensional (3D) image processing of the pore space, using dynamic models obtained from computed tomography, using different sources of radiation, and as examples of studies (Pires et al., 2010), and the effects of soil erosion on soil erosion. The density of particles (Crestana, 1992) porosity (Luo; Lin; Li, 2010; Munkholm; Heck; Deen, 2012); (Sleutel et al., 2008), distribution of the root system in a porous medium (Garbout et al., 2012; Kaestner, Schneebeli, Graf, 2006;

The objective of this work is to use microCT to compare the porosity distribution and pore connectivity density between a soil without vegetation cover and a soil with grass cover, both Ferralsols. Four undisturbed samples of each soil were collected.

\section{MATERIALS AND METHODOLOGY}

The work developed on a slope within the limits of the Stream of Thorn Microbasin, which has a total area of $9.14 \mathrm{~km} 2$ being located in the Farming Paiol, where agricultural activities related to the genetic improvement of cattle and dairy cattle are developed. The area is located in the municipality of Silva Jardim, State of Rio de Janeiro, and access is given by BR 101. (Fig.1). 


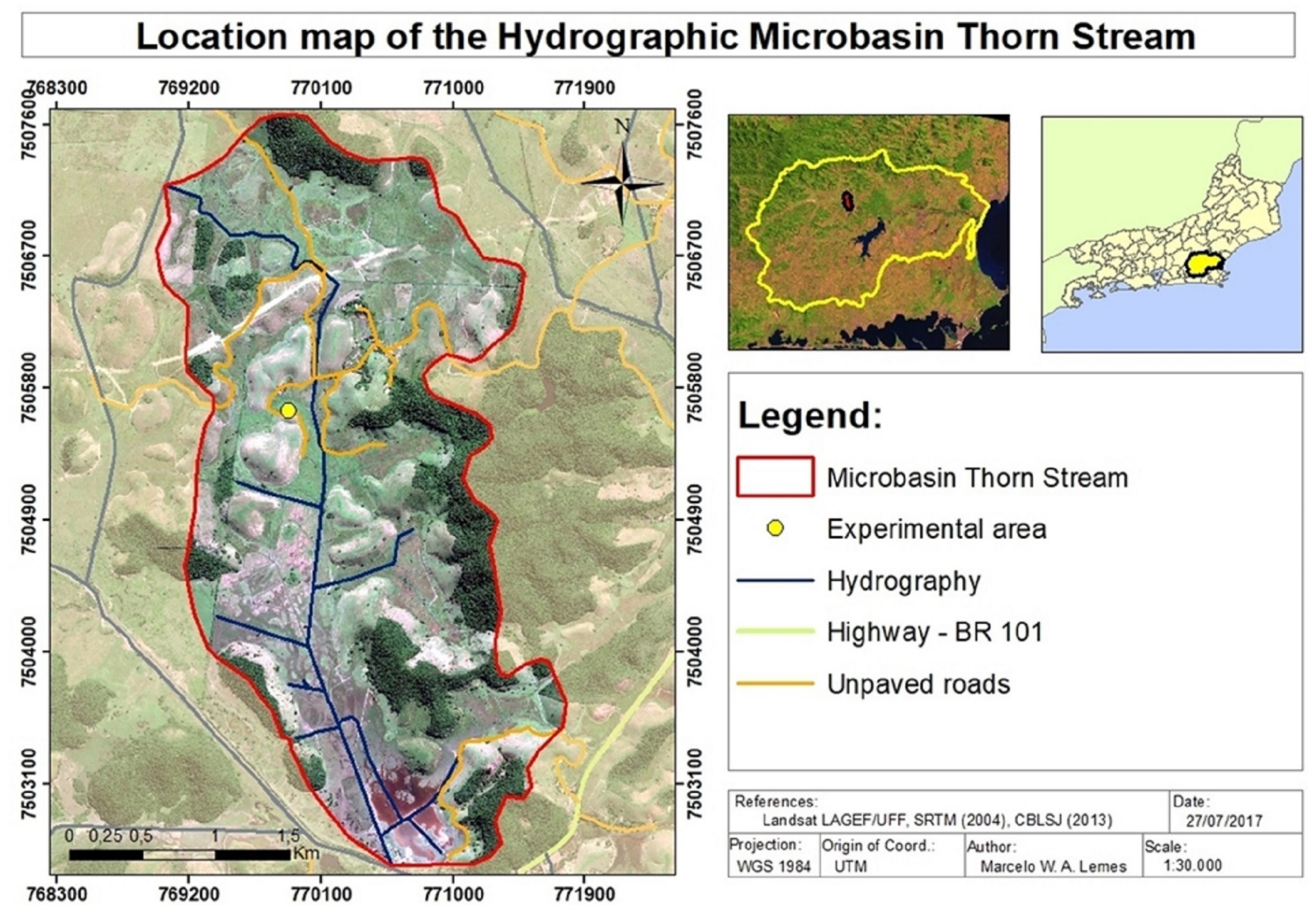

Figure 1 - Location map where the access routes, the hydrography and the delimitation of the Stream of Thorn Microbasin.

The undisturbed samples for the tests were collected on the half slope of a dissected hill within the limits established by erosion plots (A), totaling eight replicates packed in plastic film for transportation and handling without loss (B). The samples were distributed in the following way: four in soil with grass cover (1) and four in soil without vegetation cover (2), using acrylic tubes measuring $50 \mathrm{~mm}$ in height and $32 \mathrm{~mm}$ in diameter (C). (Fig. 2)
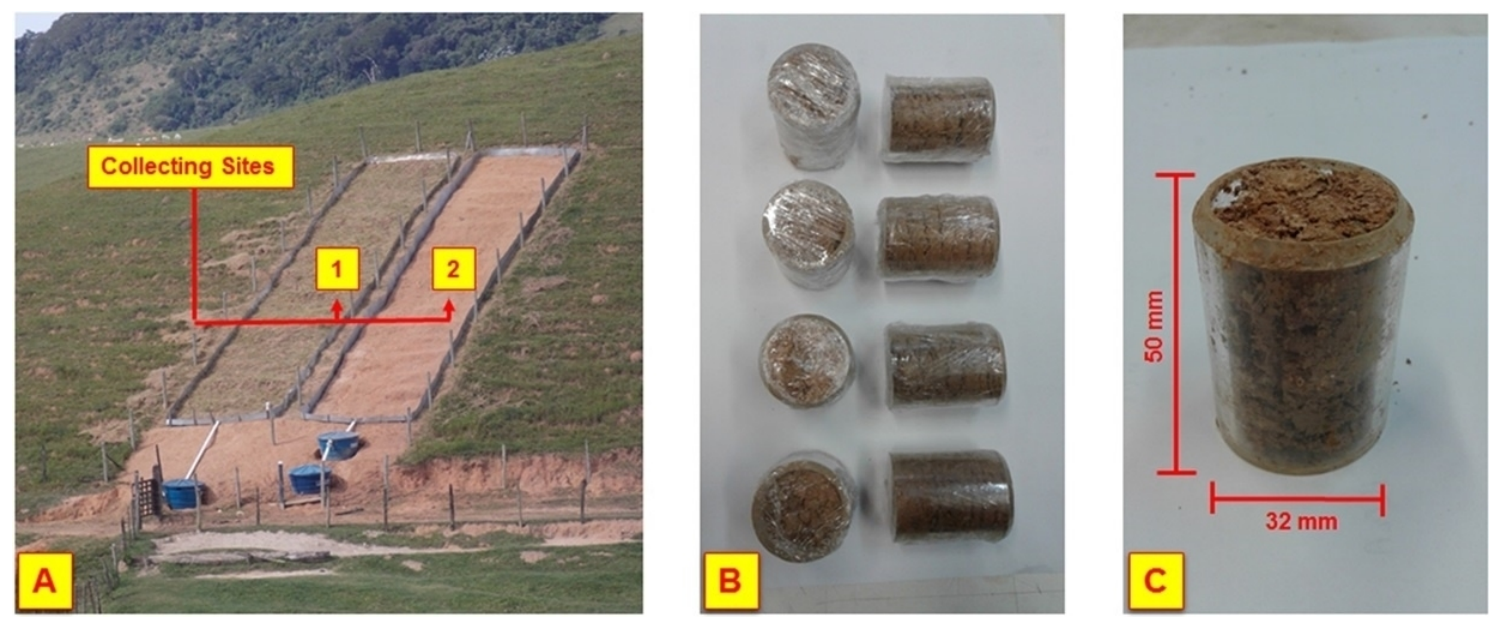

Figure 2 - Sample collection procedures.

The samples were scanned in a high energy system - Skyscan / Bruker, model1173. The Figure 3 show the microCT experimental setup. The system operates with voltage and current of $130 \mathrm{kV}$ and 61 $\mu \mathrm{A}$, respectively. A flat panel detector ( 2240 x 2240 pixels) was used to register the transmission of the $\mathrm{X}$-ray beam. All the acquisition parameters are presented in table 1. After acquisition, the image is captured and reconstructed using the FDK reconstruction algorithm, (Feldkamp; Davis; Kress, 1984). 

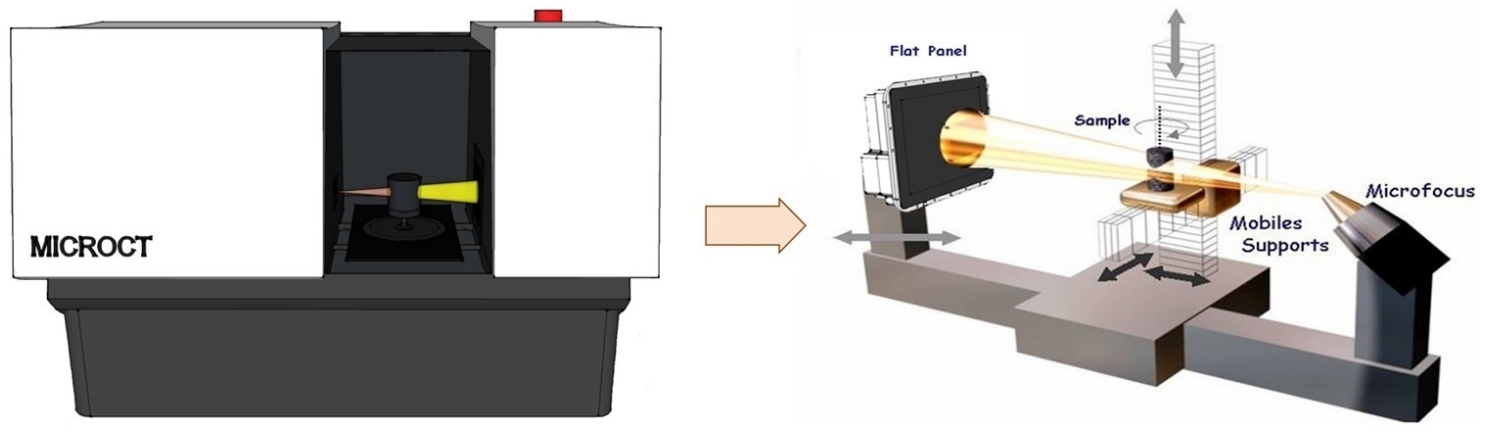

Figure 3 - MicroCT experimental setup illustration.

After reconstruction 3D models were built highlighting the porous space versus soil matrix. Then, total porosity and density of connectivity among the pores were measured. For these quantitative analyzes, the first step is to determine the region of interest (ROI) and / or volume of interest (VOI), represented respectively in two and three dimensions. ROI relate to a cross section where the 2D analysis will be carried out, while VOI relate to the sum of all the cross sections that represent a 3D volume. However, there is no law of thumb used to determine the segmentation (threshold value), (Gonzalez and Woods, 2002).

In the present study, we chose to use a adaptive method segmentation. In this method for each voxel, the threshold is calculated as the mean of all pixel/voxel grayscales within a selected radius. In this way, the binary image is obtained, with the objects (soil matrix) in white and the background (pore) in black. Thus, it was possible to quantify the total porosity and density of connectivity. The schematic of this segmentation is shown in Figure 4.
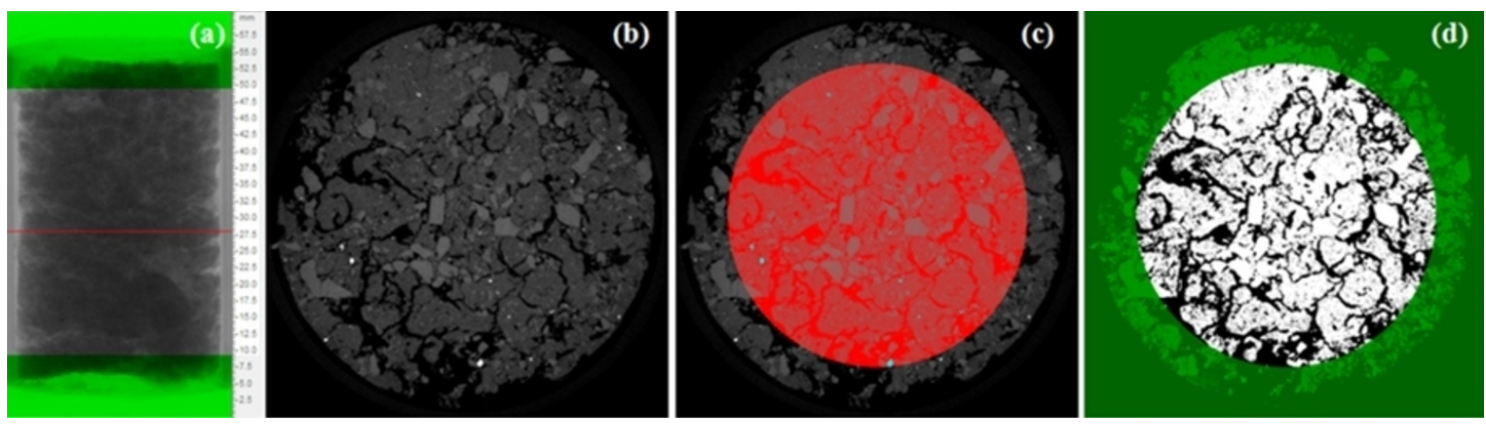

Figure 4 - Adaptive method segmentation: (a) shows the projection; (b) shows a slice; (c) shows the same slice with the ROI emphasize in red and (d) segmented image.

\section{RESULTS AND DISCUSSIONS}

To acquire the data, the values of the parameters were adjusted to acquire the information within a pattern that responded in the most accurate way, searching for the openings with the smallest possible size, in order to identify more clearly the class of Micropores. In this sense the soil pore diameters analyzed were classified according to Brewer (1964) that define micropores that have a diameter smaller than $0.03 \mathrm{~mm}$ and macropores larger than this value. 


\begin{tabular}{c|c} 
Parameter & Value \\
\hline X-ray voltage $(\mathrm{kV})$ & 130 \\
\hline Current $(\mu \mathrm{A})$ & 61 \\
\hline Detector matrix & $2240 \times 2240$ \\
\hline Pixel size $(\mu \mathrm{m})$ & 15.3 \\
\hline Rotation step (deg) & 0.5 \\
\hline Frames averaging & 5 \\
\hline Random Movement & 20 \\
\hline Filter & $1 \mathrm{~mm} \mathrm{Al}$ \\
\hline Number of Scans & 2 \\
\hline Scan duration & $1 \mathrm{~h} \mathrm{25} \mathrm{min}$
\end{tabular}

Table 1 - MicroCT measurements details.

Covered soil (CS) presented the following percentages of total porosity: $21.1 ; 24.6 ; 27.3$ and $36.7 \%$; As the soil without cover (SWC) had porosities of $13.6 ; 20.5 ; 21.8$ and $30.8 \%$. The pore densities in the covered soil were $46.7 ; 76.7 ; 155.4$ and $508.63 \mathrm{~mm} 3$, while in the uncovered terrain were $19.9 ; 45.8 ; 76.7$ and $511.3 \mathrm{~mm} 3$. The values of soil porosity presented higher values in the soil covered with grass in relation to the same pairs of soil samples without vegetation cover. This trend was also observed in the values of density of connections between the pores.

The values corresponding to macroporosity were $7.37 ; 13.78 ; 9.01$ and $12.54 \%$ on CS soil and $7.66 ; 7.48 ; 13.18 ; 12.52 \%$ not only SWC. Both coverages obtained an average very close to this index, varying only $0.46 \%$. Already the values of microporosity for the soil CS was $13.75 ; 10.91 ; 18.37$ and $24.17 \%$, in SWC soil the indices were in the houses of $5.94 ; 13.08 ; 8.71$ and 18.36 . In this cyst it is noticed that there is evidence for CS soil, showing an average 5\% higher than SWC soil. This can be explained because the permanence of the vegetal cover increases organic matter in the soil, it keeps the root system active and assists in the stability of its aggregates generating an increase of the microporisdade according to Viana et al (2011).

\begin{tabular}{|c|c|c|c|c|c|}
\hline \multirow{2}{*}{ Samples } & & \multicolumn{4}{|c|}{ Retention Curve } \\
\hline & & Total Porosity (\%) & Macropores (\%) & Micropores (\%) & Soil density $\left(\mathrm{g} / \mathrm{cm}^{3}\right)$ \\
\hline \multirow{4}{*}{ 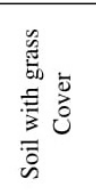 } & 1 & 49.45 & 8.95 & 40.90 & 2.52 \\
\hline & 2 & 52.86 & 15.16 & 42.10 & 2.63 \\
\hline & 3 & 50.78 & 9.98 & 35.80 & 2.53 \\
\hline & 4 & 53.66 & 14.36 & 41.10 & 2.59 \\
\hline \multirow{4}{*}{ 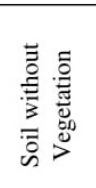 } & 5 & 46.15 & 5.25 & 40.50 & 2.59 \\
\hline & 6 & 45.10 & 3.00 & 37.70 & 2.57 \\
\hline & 7 & 47.03 & 11.23 & 40.80 & 2.53 \\
\hline & 8 & 43.24 & 2.14 & 39.30 & 2.57 \\
\hline
\end{tabular}

Table 2 - Distribution of porosity and connectivity density in different systens of use.

In order to obtain a standard of comparison, the soil water retention curve test was carried out in soil samples from the same aforementioned environments (CS and SWC), which presents several practical, technical and scientific applications, such as: The determination of the soil field capacity, the permanent wilting point and the total availability of water in the soil, indispensable variables for an adequate irrigation management, soil water balance and macro and micro porosity (Table 2).

One of the ways to determine the water retention curve in the soil is to use the Richards pressure 
chamber, which simulates a determined tension in the soil sample and later, by weight difference (wet soil after being subjected to pressure - Soil dried in an oven at $105^{\circ} \mathrm{C}$ for 48 hours), the water content related to the applied voltage is determined. For all eight samples submitted to the assay an eight-strain sequence was applied on the following increasing scale: $0.01 ; 0.033 ; 0.06 ; 0.33 ; 1.00 ; 5.00$ and 15.00 bar.

What is evident when carrying out a relationship with both methods is that the Retention Curve is larger than the Computed Microtomography because this method can identify a greater percentage of microporosity reaching the house of $23.17 \%$ more in the soil CS and $28.05 \%$ in soil SWC. This is due to the fact that the maximum resolution of the MCT reaches the equivalent of $0.03 \mathrm{~mm}$, however there are a series of pores with smaller sizes that are not identified by the tomographic sensors. Regarding macroporosity data, the Retention Curve showed an average of $12.11 \%$ for CS soil and $5.40 \%$ for SWC soil. In this same index for MCT, $10.21 \%$ for CC soils and 11.52 for SWC were presented. This demonstrates a greater capacity of the microtomography in the identification of pores larger than $0.03 \mathrm{~mm}$, mainly to environments that have already been worn in compacts for a period of five years.

\begin{tabular}{|c|c|c|c|c|c|}
\hline \multirow{2}{*}{\multicolumn{2}{|c|}{ Samples }} & \multicolumn{4}{|c|}{ Computerized Microtomography } \\
\hline & & \multirow{2}{*}{$\begin{array}{c}\text { Total Porosity (\%) } \\
21.12\end{array}$} & \multirow{2}{*}{$\begin{array}{c}\text { Macropores }(\%) \\
7.37\end{array}$} & \multirow{2}{*}{$\begin{array}{c}\text { Micropores (\%) } \\
13.75\end{array}$} & \multirow{2}{*}{$\begin{array}{c}\text { Connectivity Density }\left(\mathrm{mm}^{3}\right) \\
46.03\end{array}$} \\
\hline \multirow{4}{*}{ 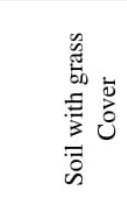 } & 1 & & & & \\
\hline & 2 & 24.69 & 13.78 & 10.91 & 76.76 \\
\hline & 3 & 27.38 & 9.01 & 18.37 & 155.42 \\
\hline & 4 & 36.71 & 12.54 & 24.17 & 508.63 \\
\hline \multirow{4}{*}{ 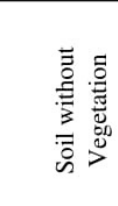 } & 5 & 13.60 & 7.66 & 5.94 & 19.91 \\
\hline & 6 & 20.56 & 7.48 & 13.08 & 45.84 \\
\hline & 7 & 21.89 & 13.18 & 8.71 & 76.79 \\
\hline & 8 & 30.88 & 12.52 & 18.36 & 511.13 \\
\hline
\end{tabular}

Table 3 - Distribution of the values processed by Retention Curve.

To evaluate the total porosity and soil structure after reconstruction of the images from the Microtomography data, the following templates will be used (Fig. 5). This will allow the visual localization of the information described in a more dynamic and fast way. This porosity profile is constructed from the slice evaluation by slice of the whole sample body measuring $5.0 \mathrm{~cm}$.
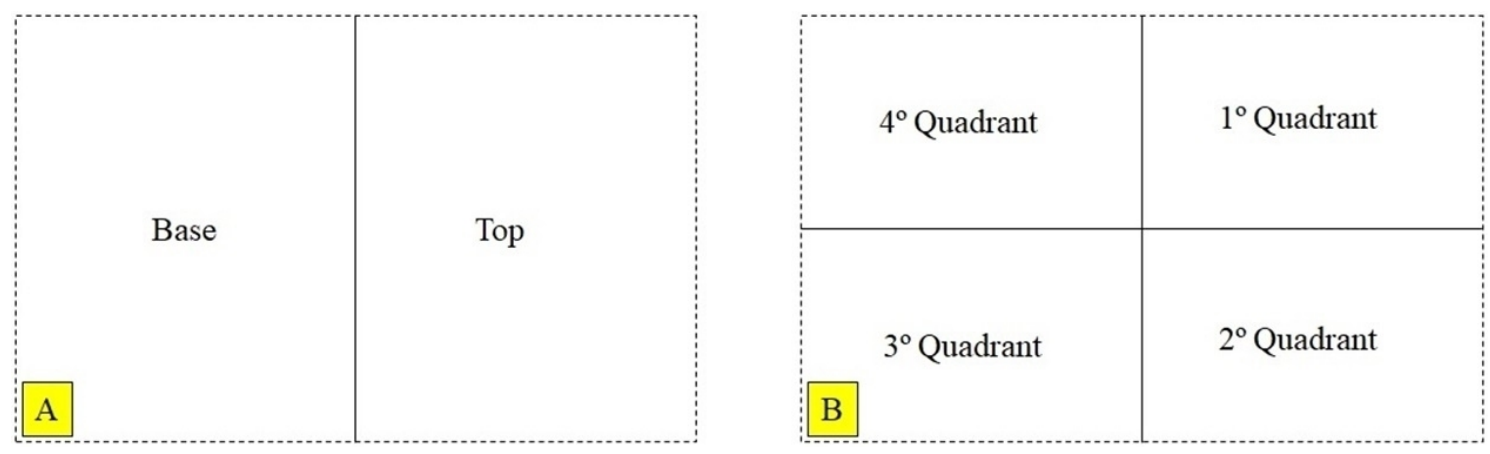

Figure 5 - A - Template for porosity profile relation with each soil sample. B - Positioning template with the coronal images obtained in the reconstruction of the microtomography

The porosity profile of sample 1 (Fig. 6.1), which corresponds to the system with coverage (CS), concentrates around $24 \%$ of the porosity at the base and gradually decreases this value with the proximity of the surface. In the first few centimeters there is a significant increase in relation to the average of the whole body of the sample, going from $8.0 \%$ to $16 \%$ in a few centimeters of difference. If 
we correlate these values with the coronal profile image (Fig. 7.1) of the same sample we can see the presence of some significant voids in the 2 nd and 3rd quadrant that corroborate with the presented values.

In the sample 2CS (Fig. 6.2) the porosity at the base is $25 \%$, presented a considerable increase, rising to $37.5 \%$ in a space of $1 \mathrm{~cm}$ and then decreasing gradually to $2.5 \mathrm{~cm}$ in height, later the values present An increase of the total porosity until reaching the top of the sample with $44 \%$. These high values at the beginning of the base and at the top of the top are visually confirmed by observing that the coronal profile (Fig. 7.2) shows a large crack in the 1st quadrant and a contrast between matrix and well-disaggregated pores.

The sample 3CS (Fig. 6.3) has a very similar behavior with the previous sample, the porosity in the base is high because of a defragmentation presented by the sample in the 4th quadrant (Fig. 7.3) which also occurs in the third elevating quadrant The porosity in the final centimeters of the top, reaching $40 \%$.

The last soil sample with 4CS coverage (Fig. 6.4), has a high porosity at the base (35\%) and a lower percentage at the top (34\%). However, in the centimeters that precede the top, it presents a $20 \%$ elevation of the house because of circular spaces that can be understood as paths of the microfauna of the soil or old roots that were incorporated to the organic matter. This occurs in the 1 st and 2 nd quadrant (Fig. 7.4).

However, in the soil samples without vegetation cover (SWC) the behavior was slightly different. In the sample 1SWC (Fig. 6.5) the porosity in the base is in the $10 \%$ and has its highest values at the top, reaching $36 \%$, which is evidenced by the concentration of mineral matrix in the 3rd and 4th quadrants (Fig. 7.5).

In the sample 2SWC (Fig. 6.6) the base already presents high porosity starting from 39\%, reaching $56 \%$ at the top. The presence of ducts explains this increase according to height, especially in the 1st quadrant (Figure 7.6). The sample 7SWC (Figure 6.7) presents a porosity of $38 \%$ at the base and reaching $40 \%$ at the top, it is observed that at the ends of all the quadrants there is an evident disintegration of particles, since the matrix region is with faults of Occurrence (Fig. 7.7).

In the last sample 4SWC (Fig. 6.8) a fluctuation of the values occurs, since cracks denoting porosity are observed throughout the sample length (Fig. 7.8). In the 1st and 2nd quadrants, the values rise in a very generalized way because there is an opening in the soil that could have been constructed by roots or by the contraction of the soil after the procedures of preparation of the samples, mainly the drying. 

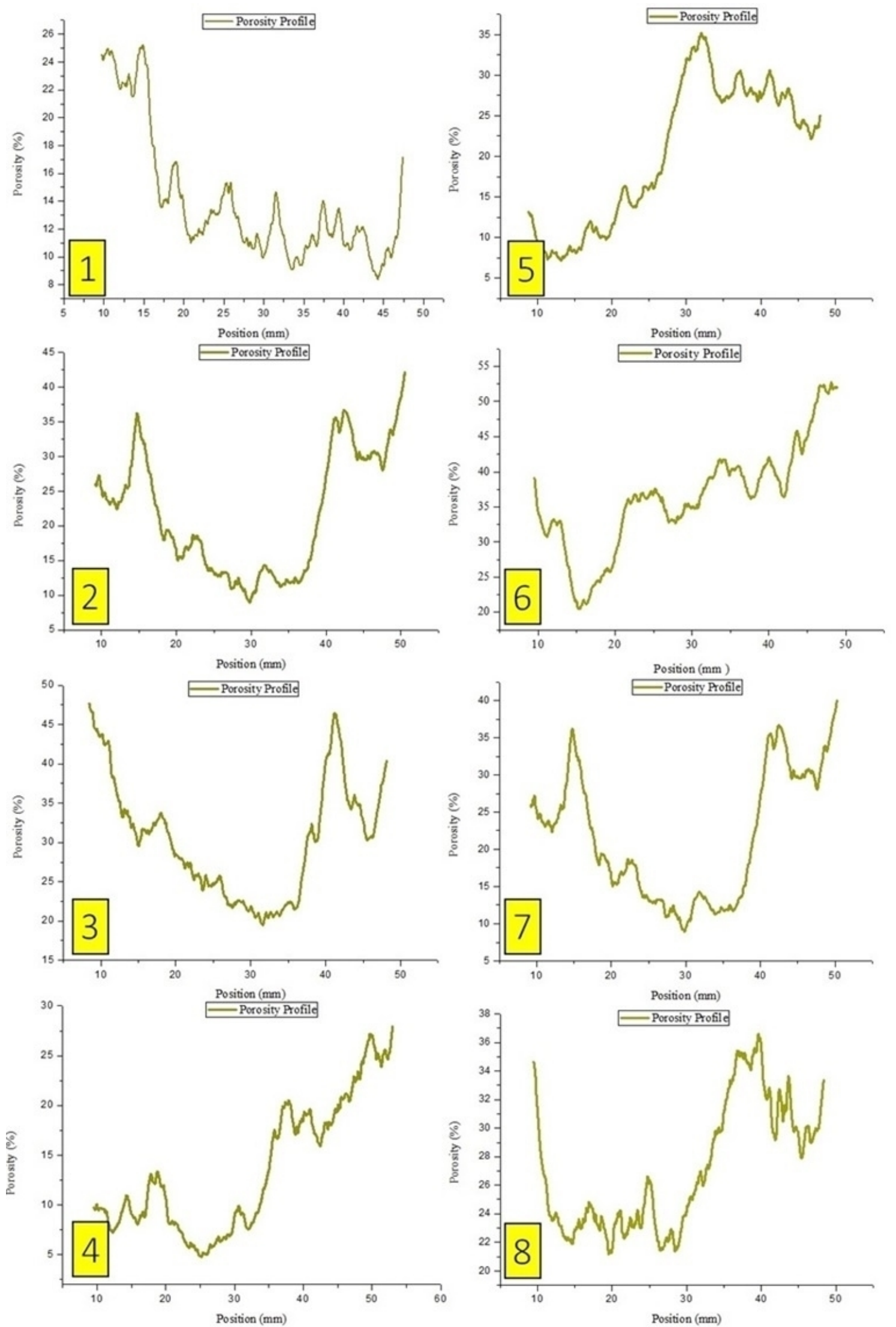

Figure 6 - Porosity profiles of the eight soil samples submitted to the Computerized Microtomography. 

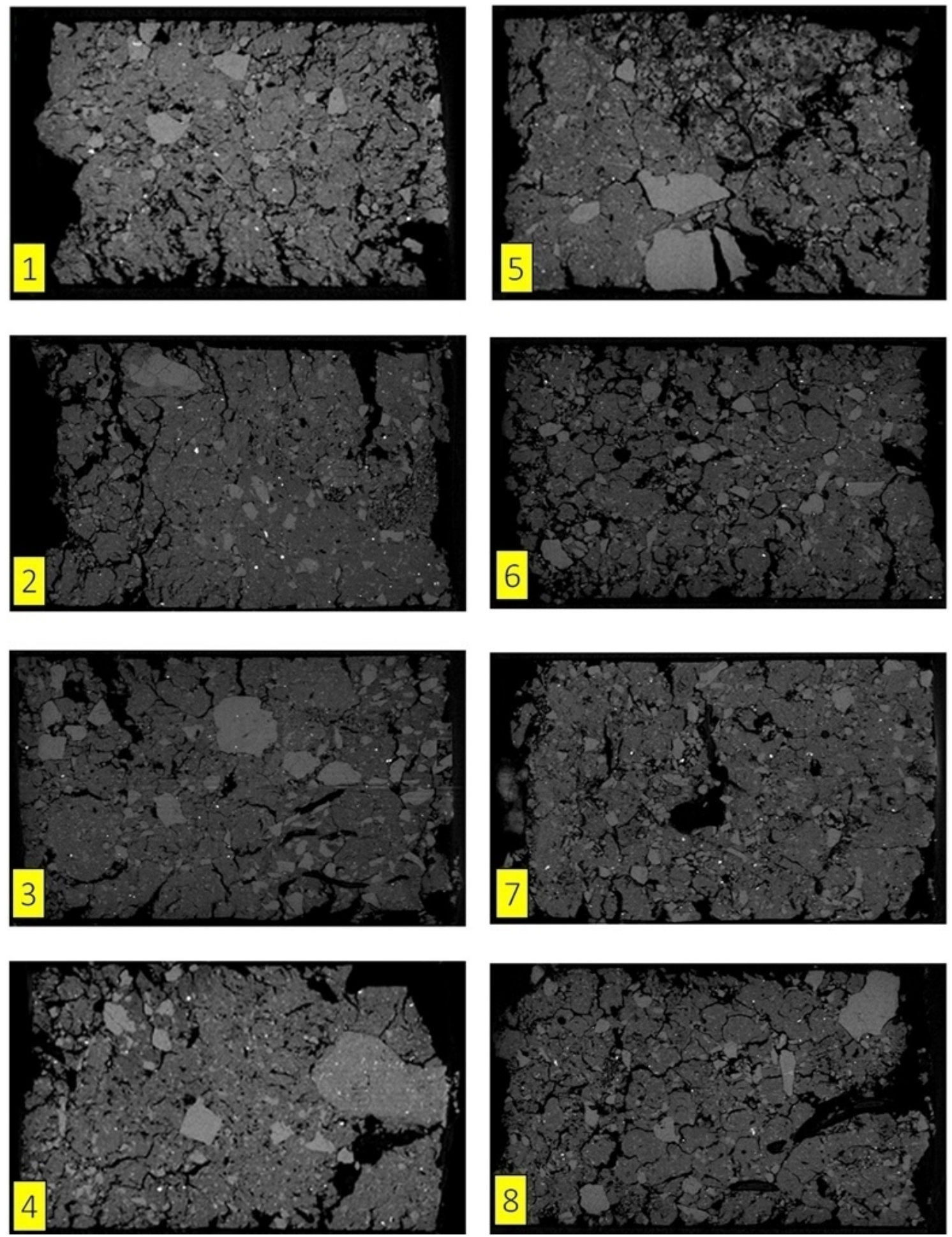

Figure 7 - Reconstruction of the coronal profiles of the soil samples images after being processed in the tomograph. 

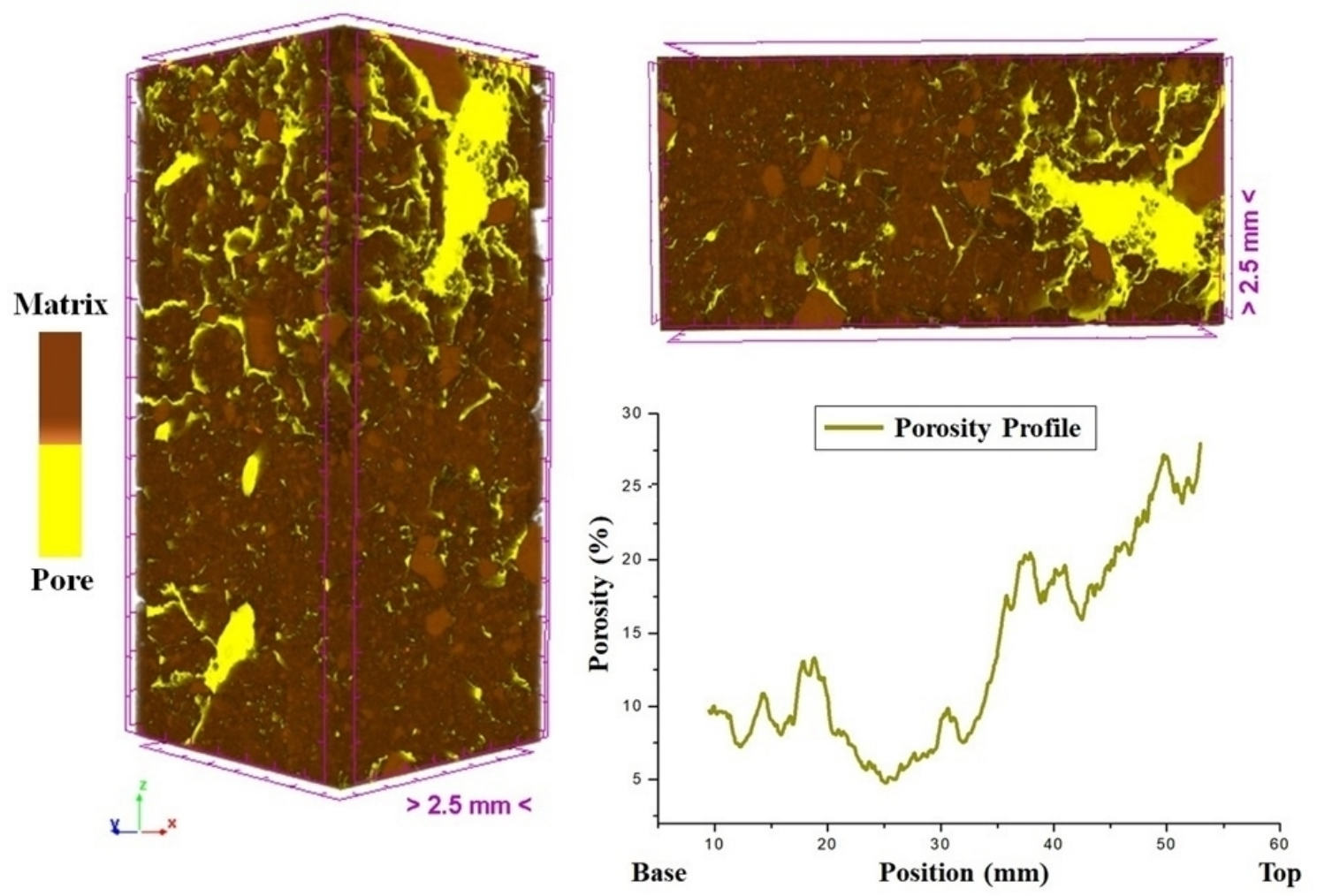

Figure 8 - Pore distribution and 3D representation of a sample of plant-covered soil with the highest porosity.
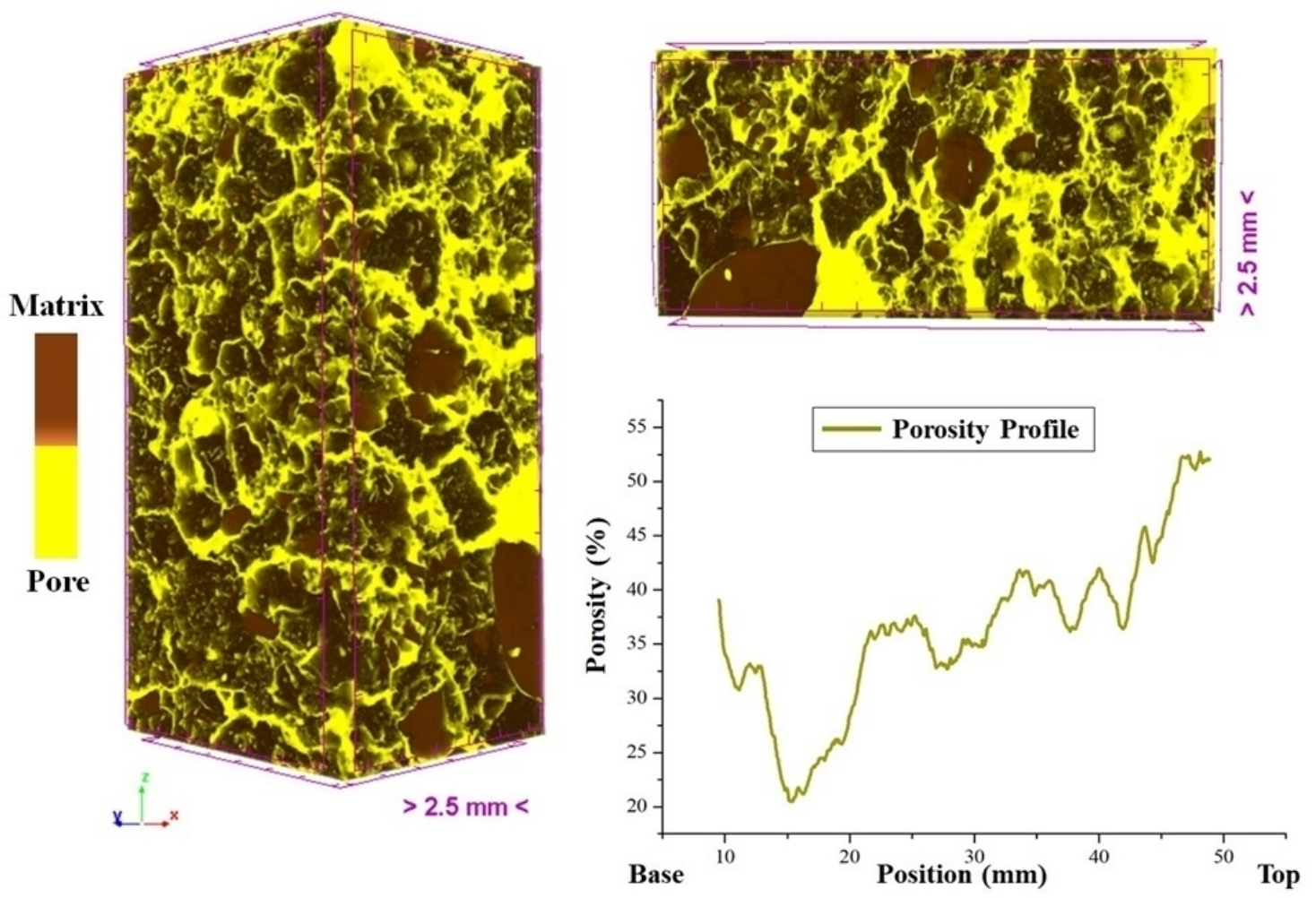

Figure 9 - Pore distribution and 3D representation of a sample of plant-covered soil with the highest porosity. 


\section{CONCLUSIONS}

The results show that the presence of the vegetal cover is a relevant factor in the increase of the porosity of the superficial layers of the soil, because the root system develops ducts that are connected with the progress of its development. In this sense, identified a concentration of $18.60 \mathrm{~g} / \mathrm{dm} 3$ of organic carbon in the A horizon of this soil, which may aid in the stability of aggregates and condition the occurrence of pores. On the other hand, the lack of vegetation cover considerably reduces the pore indices of the superficial layers of the soil, which can be explained by the fact that the sealing process of the exposed soil occurs when the material disaggregated by erosion caused by the impact of the raindrops (Splash) obliterates the pores, corroborating with this hypothesis identified, for the same area, very high apparent density values for horizon A, at the house of $1.45 \mathrm{~g} / \mathrm{dm} 3$. Thus, the MicroCT technique demonstrated an efficient and non-destructive tool for the analysis and characterization of the pore structure of soils protected from and degraded by erosion, underlining clear differences between them, as expected.

\section{ACKNOWLEDGMENTS}

The authors would like to thank EMBRAPA for the partnership, as well as, CAPES and FAPERJ for the financial supports. The author thanks UNESA for the Research and Productivity Exchange.

\section{REFERENCES}

BREWER, R., 1964. Fabric and mineral analysis of soils. Huntington, N.Y.: R.E. Krieger. Crestana, S., 1992. Calibração e Uso de um Tomógrafo Computadorizado em Ciência do Solo. Revista Brasileira de Ciência do Solo. 16, 161-167.

FELDKAMP, L.A., DAVIS, L.C., KRESS, J.C., 1984. Pratical cone beam algorithm. Journal of the Optical Society of America. 1(6), 612-619.

GONZALEZ, R.C. \& WOODS, R.E., 2002. Digital Image Processing, 2nd Ed. Prentice Hall, USA.

GARBOUT, A., MUNKHOLM, L.J.; HANSEN, S.B., PETERSEN, B.M.,MUNK, O.L., PAJOR, R., 2012. The use of PET/CT scanning technique for 3D visualization and quantification of real-time soil/plant interactions. Plant and Soil, The Hague. 352, 113-127.

HILLEL, D., 1972. Soil and water: physical principles and processes. 3rd. Ed. New York: Academic, 288.

KAESTNER, A.; SCHNEEBELI, M.; GRAF, F., 2016. Visualizing threedimensional root networks using computed tomography. Geoderma. 136, 459-469.

LUO, L.; LIN, H., LI, S., 2010. Quantification of 3-D soil macropore networks in different soil types and land uses using computed. Journal of Hydrology, in press.

MACHADO, A.S., DAL Bó, P.F.F., LIMA, I., BORGHI, L., LOPES, R., 2015. X-ray microtomography characterization of carbonate microbialites from a hypersaline coastal

lagoon in the Rio de Janeiro state - Brazil. Nuclear Instruments and Methods in Physics Research Section A. 784, 574-580.

MUNKHOLM, L. J., HECK, R.J., DEEN, B., 2012. Soil pore characteristics assessed from Xray micro-CT derived images and correlations to soil friability. Geoderma. 181-182, 22-29.

PIRES, L.F., BORGES, J.A.R., BACCHI, O.S., REICHARDT, K., 2010. Twenty-five years of computed tomography in soil physics: A literature review of the Brazilian contribution. Soil \& Tillage Research. 110, 197-210.

SLEUTEL, S., BOUCKAERT, L., BUCHAN, D., VAN LOO, D., CORNELIS, W.M., SANGA. H.G., 2012. Manipulation of the soil pore and microbial community structure in soil mesocosm incubation 
studies. Soil Biology and Biochemistry. 45, 40-48.

STUMPF, L.; PAULETTO, E. A.; FERNANDES, F. F.; SUZUKI, L. E. A. K.; SILVA. T. S.; PINTO, L. F. S. \& LIMA, C. L. R., 2014. Perennial grasses for recovery of the aggregation capacity of a reconstructed soil in a coal mining area in southern brazil. Revista Brasileira Ciência do Solo. 38, 327-335.

TAVARES FILHO, J., TESSIER, D., 2009. Characterization of soil structure and porosity under long-term conventional tillage and no-tillage systems. Revista Brasileira Ciência do Solo. 33, 1837-1844. 